\title{
Do angiotensin II type 1 receptor blockers have molecular effects?
}

\author{
Shin-ichiro Miura and Keijiro Saku \\ Hypertension Research (2010) 33, 105-106; doi:10.1038/hr.2009.202; published online 27 November 2009
}

\begin{abstract}
A ngiotensin II (Ang II) type $1\left(\mathrm{AT}_{1}\right)$ receptor blockers (ARBs) are highly selective for the $\mathrm{AT}_{1}$ receptor and block the deleterious effects of Ang II. ${ }^{1}$ Many ARBs are available for clinical use worldwide. Recent clinical and basic studies have shown that not all ARBs have the same effects and some benefits conferred by ARBs may not be class effects, but rather molecular effects. ${ }^{2}$ However, it is still controversial whether each ARB has molecular effects in a clinical setting.
\end{abstract}

In this issue of Hypertension Research, Tsutamoto et al. ${ }^{3}$ have reported that replacing candesartan with olmesartan decreased the left ventricular mass index (LVMI) without changing blood pressure (BP) in patients with essential hypertension. This study indicated that ARBs did not all have the same effects on LVMI. Each ARB has been shown to have unique molecular effects in basic experimental studies, and these effects may be because of small differences in the molecular structure of each ARB. ${ }^{2}$ Although olmesartan and candesartan have common molecular structures (biphenyl tetrazol and imidazol groups), olmesartan contains a hydroxyl group in addition to an $\alpha$-carboxyl group in the imidazol ring, whereas candesartan only has an $\alpha$-carboxyl group. The hydroxyl group and carboxyl group of olmesartan are important for tightly binding to $\mathrm{AT}_{1}$ receptor and for strong inverse agonism against inositol phosphate production. ${ }^{4}$ The inverse agonism of olmesartan was stronger than that of cande-

Dr S Miura and Professor K Saku are at the Department of Cardiology, Fukuoka University School of Medicine, Fukuoka, Japan; and S Miura is also at the Department of Molecular Cardiology, Cleveland Clinic Foundation, $\mathrm{OH}$, USA.

E-mail:miuras@cis.fukuoka-u.ac.jp sartan..$^{5}$ The structure of olmesartan might be associated with the differential effects of olmesartan and candesartan on LVMI. In contrast, mechanical stress activates $\mathrm{AT}_{1}$ receptor (activation of extracellular signalregulated protein kinases (ERKs)) independent of Ang II, and this activation can be inhibited by candesartan. ${ }^{6,7}$ Zou et al. ${ }^{6}$ also examined pressure overload on the heart by constricting the transverse aorta of adult male angiotensinogen knockout mice. Although treatment with candesartan did not reduce BP, candesartan significantly attenuated the development of cardiac hypertrophy. ${ }^{6}$ In addition, olmesartan also blocked mechanical stress-induced ERKs activation through $\mathrm{AT}_{1}$ receptor. ${ }^{8}$ There may be no difference in the blockade of mechanical stress-induced ERKs activation between olmesartan and candesartan. On the basis of those experimental studies, olmesartan and candesartan offered similar benefits for mechanical stressinduced ERKs activation, but there was a different clinical outcome in the Tsutamoto's study. ${ }^{3}$ In contrast, there was a similar clinical outcome among ARBs, even though ARBs have different benefits on the basis of experimental studies. The presence of molecular effects for each ARB, according to experimental studies, does not necessarily reflect the clinical outcome. It is still controversial whether each $\mathrm{ARB}$ has unique molecular effects in a clinical setting, even though there are several differences among ARBs in experimental studies.

Recently, many studies have provided new insights regarding the renin-angiotensin system (RAS), such as the homo- and heterooligomerization of Ang II receptors, 9,10 $\mathrm{AT}_{1}$ receptor-associated protein, ${ }^{11} \mathrm{AT}_{2}$ receptor-interacting protein $^{12}$ and Ang-(1-7) through the catalytic activity of angiotensinconverting enzyme-2 (ACE2). ${ }^{13}$ In the RAS, besides Ang II, other bioactive RAS fragments, such as Ang III, Ang IV and Ang-(1-7), have recently been characterized. ACE2 is the main enzyme responsible for the conversion of Ang II to Ang-(1-7). ${ }^{13}$ Ang-(1-7) binds to a $G$ protein-coupled receptor Mas. ${ }^{14}$ In particular, Ang-(1-7) is interesting because of its selectivity, which may be due to the absence of phenylalanine in the C-terminal position of Ang II, which is important for binding to and activating the $\mathrm{AT}_{1}$ receptor. Iwai and Horiuchi have reviewed it in great detail and concluded that the classic ACEAng II-AT ${ }_{1}$ receptor axis acts as a 'devil,' whereas the ACE2-Ang-(1-7)-Mas axis acts as an 'angel' in the RAS. ${ }^{15}$ This point of view is critical for the assessment of Tsutamoto's results. Tsutamoto et al. ${ }^{3}$ have observed that replacing candesartan with olmesartan decreased plasma Ang II without changing plasma aldosterone. Although they did not analyze plasma levels of Ang-(1-7), they suggested that plasma levels of Ang-(1-7) may be increased in association with the decrease in Ang II after replacement, because a previous report indicated that olmesartan increased ACE2 expression in association with an increase in plasma Ang-(1-7) after myocardial infarction in rats. ${ }^{16}$ However, in the rats, olmesartan also increased plasma Ang II levels and ACE2 mRNA increased in the heart. As local expression of the RAS components in the heart is independent of the systemic RAS, cardiac ACE2 levels may not directly influence plasma levels of Ang-(1-7). In addition, Takeda et al. ${ }^{17}$ reported that treatment with candesartan also increased ACE2 mRNA and decreased angiotensinogen mRNA in the rat heart. It is not easy to 
Table 1 Direct comparison of the efficacies of ARBs in clinical trials

\begin{tabular}{|c|c|}
\hline Effects & Efficacies \\
\hline Reducing left ventricular mass ${ }^{18}$ & Val $>$ Los \\
\hline Lowering plasma PAI-1 and MCP-19 & Can $>$ Los \\
\hline Preventing coronary artery contraction 20 & Ex $>$ Can \\
\hline Preventing coronary restenosis ${ }^{21}$ & Val $>$ Los \\
\hline Reducing CRP22 & Olm $>$ Val \\
\hline Reducing plasma Ad and Glu²3 & Tel $>$ Can \\
\hline Inhibiting platelet activation ${ }^{24}$ & Los $>$ Val \\
\hline Reducing IL- 6 and CRP25 & Olm $>$ Tel \\
\hline Improving Glu and lipid profiles ${ }^{26}$ & $\mathrm{Tel}>\mathrm{Olm}$ \\
\hline
\end{tabular}

Abbreviations: Ad, adiponectin; Angiotensin II type 1 receptor blocker; Can, candesartan; CRP, C-reactive protein; Ex, Exp3174; Glu, glucose; IL-6, interleukin-6; Los, losartan; MCP-1, monocyte chemoattractant protein-1; Olm, olmesartan; PAI-1, plasminogen activator-inhibitor type-1 antigen; Tel, telmisartan; Val, valsartan.

conclude that the difference in the effects of olmesartan and candesartan are due to ACE2 activity. Although we do not yet know whether the benefit is due to a molecular effect, the replacement of candesartan with olmesartan was effective.

Over the past decade, the efficacies of ARBs have been compared and differences have been observed in clinical studies (Table 1). Valsartan is more effective than losartan at reducing LVMI. ${ }^{18}$ Candesartan significantly lowered plasma plasminogenactivator inhibitor type-1 and monocyte chemoattractant protein-1. ${ }^{19}$ The ARB Exp3174 effectively prevented human coronary artery contraction. ${ }^{20}$ Valsartan decreased the rate of target lesion revascularization after stenting. ${ }^{21}$ Olmesartan showed a significant reduction of high-sensitive C-reactive protein. $^{22}$ Changes in serum adiponectin and plasma glucose were significantly greater in a telmisartan group. ${ }^{23}$ Losartan significantly reduced human platelet activation. ${ }^{24}$ These differences in the effects of ARBs are independent of BP lowering. Interestingly, when olmesartan was compared with telmisartan, conflicting data were reported. ${ }^{25,26}$ There were no differences between ARBs with regard to their effects on metabolic parameters, including hemoglobin Alc and adiponectin. ${ }^{25}$ In contrast, telmisartan was more beneficial for improving glucose and lipid profiles. ${ }^{26}$

In conclusion, clinical trials, including that of Tsutamoto et al., ${ }^{3}$ have shown that ARBs have different degrees of benefits. Some effects may be due to molecular effects, whereas most of the benefits conferred by ARBs are class effects. As these trials were relatively small, we must be careful when comparing their results and interpreting their clinical impact, and should also reconsider whether these are molecular effects of ARBs, rather than class effects.

\section{CONFLICT OF INTEREST}

The authors declare no conflict of interest.

1 de Gasparo M, Catt KJ, Inagami T, Wright JW, Unger T. International Union of Pharmacology. XXIII. The angiotensin II receptors. Pharmacol Rev 2000; 52: 415-472.

2 Miura S, Fujino M, Saku K. Angiotensin II receptor blocker as an inverse agonist: a current perspective. Curr Hypertens Rev 2005; 1: 115-121.

3 Tsutamoto T, Nishiyama K, Yamaji M, Kawahara C, Fujii M, Yamamoto T, Horie M. Comparison of the long-term effects of candesartan and olmesartan on plasma angiotensin II and left ventricular mass index in patinets with hypertension. Hypertens Res (e-pub ahead of print 20 November 2009; doi:10.1038/hr.2009.192).

4 Miura S, Fujino M, Hanzawa H, Kiya Y, Imaizumi S, Matsuo Y, Tomita S, Uehara Y, Karnik SS, Yanagisawa $\mathrm{H}$, Koike H, Komuro I, Saku K. Molecular mechanism underlying inverse agonist of angiotensin II type 1 receptor. J Biol Chem 2006; 281: 19288-19295.

5 Le MT, Vanderheyden PM, Szaszák M, Hunyady L, Kersemans V, Vauquelin G. Peptide and nonpeptide antagonist interaction with constitutively active human AT1 receptors. Biochem Pharmacol 2003; 65: 1329-1338.

6 Zou Y, Akazawa H, Qin Y, Sano M, Takano H, Minamino T, Makita N, Iwanaga K, Zhu W, Kudoh S, Toko H, Tamura K, Kihara M, Nagai T, Fukamizu A, Umemura S, liri T, Fujita T, Komuro I. Mechanical stress activates angiotensin II type 1 receptor without the involvement of angiotensin II. Nat Cell Biol 2004; 6: 499-506.

7 Yasuda N, Miura S, Akazawa H, Tanaka T, Qin Y, Kiya Y, Imaizumi S, Fujino M, Ito K, Zou Y, Fukuhara S, Kunimoto S, Fukuzaki K, Sato T, Ge J, Mochizuki N, Nakaya H, Saku K, Komuro I. Conformational switch of angiotensin II type 1 receptor underlying mechanical stress-induced activation. EMBO Rep 2008; 9: 179-186.

8 Qin Y, Yasuda N, Akazawa $\mathrm{H}$, Ito K, Kudo Y, Liao CH, Yamamoto R, Miura S, Saku K, Komuro I. Multivalent ligand-receptor interactions elicit inverse agonist activity of $\mathrm{AT}_{1}$ receptor blockers against stretch-induced $\mathrm{AT}_{1}$ receptor activation. Hypertens Res 2009; 32 : 875-883.

9 AbdAlla S, Lother H, Abdel-tawab AM, Quitterer U. The angiotensin II AT2 receptor is an AT1 receptor antagonist. J Biol Chem 2001; 276: 39721-39726.

10 Miura S, Miura S, Karnik SS, Saku K. Constitutively active homo-oligomeric angiotensin II type 2 receptor induces cell signaling independent of receptor conformation and ligand stimulation. J Biol Chem 2005; 280: 18237-18244.

11 Daviet L, Lehtonen JY, Tamura K, Griese DP, Horiuchi M, Dzau VJ. Cloning and characterization of ATRAP, a novel protein that interacts with the angiotensin II type 1 receptor. J Biol Chem 1999; 274: 17058-17062.

12 Nouet S, Amzallag N, Li JM, Louis S, Seitz I, Cui TX, Alleaume AM, Di Benedetto M, Boden C, Masson M, Strosberg AD, Horiuchi M, Couraud PO, Nahmias C. Trans-inactivation of receptor tyrosine kinases by novel angiotensin II AT2 receptor-interacting protein, ATIP. J Biol Chem 2004; 279: 28989-28997.

13 Tipnis SR, Hooper NM, Hyde R, Karran E, Christie G, Turner AJ. A human homolog of angiotensin-converting enzyme. Cloning and functional expression as a captopril-insensitive carboxypeptidase. J Biol Chem 2000; 275: 33238-33243.

14 Santos RA, Simoes e Silva AC, Maric C, Silva DM, Machado RP, de Buhr I, Heringer-Walther S, Pinheiro SV, Lopes MT, Bader M, Mendes EP, Lemos VS, Campagnole-Santos MJ, Schultheiss HP, Speth R, Walther T. Angiotensin-(1-7) is an endogenous ligand for the G protein-coupled receptor Mas. Proc Natl Acad Sci USA 2003; 100: 8258-8263.

15 Iwai M, Horiuchi M. Devil and angel in the reninangiotensin system: ACE-angiotensin II-AT1 receptor axis vs ACE2-angiotensin-(1-7)-Mas receptor axis. Hypertens Res 2009; 32: 533-536.

16 Ishiyama Y, Gallagher PE, Averill DB, Tallant EA, Brosnihan KB, Ferrario CM. Upregulation of angiotensin-converting enzyme 2 after myocardial infarction by blockade of angiotensin II receptors. Hypertension 2004; 43: 970-976.

17 Takeda Y, Zhu A, Yoneda T, Usukura M, Takata H, Yamagishi M. Effects of aldosterone and angiotensin II receptor blockade on cardiac angiotensinogen and angiotensin-converting enzyme 2 expression in Dahl salt-sensitive hypertensive rats. Am J Hypertens 2007; 20: 1119-1124.

18 Picca M, Agozzino F, Pelosi G. Effects of losartan and valsartan on left ventricular hypertrophy and function in essential hypertension. Adv Ther 2004; 21: 76-86.

19 Krämer C, Sunkomat J, Witte J, Luchtefeld M, Walden M, Schmidt B, Tsikas D, Böger RH, Forssmann WG, Drexler H, Schieffer B. Angiotensin II receptor-independent antiinflammatory and antiaggregatory properties of losartan: role of the active metabolite EXP3179. Circ Res 2002; 90: 770-776.

20 Pantev E, Stenman E, Wackenfors A, Edvinsson L, Malmsjo M. Comparison of the antagonistic effects of different angiotensin II receptor blockers in human coronary arteries. Eur J Heart Fail 2002; 4: 699-705.

21 Iwata A, Miura S, Imaizumi S, Kiya Y, Nishikawa H, Zhang B, Shimomura H, Kumagai K, Matsuo K, Shirai K, Saku K. Do valsartan and losartan have the same effects in the treatment of coronary artery disease? Circ J 2007; 71: 32-38.

22 Sugihara M, Miura S, Takamiya Y, Kiya Y, Arimura T, Iwata A, Kawamura A, Nishikawa H, Uehara Y, Saku K. Safety and efficacy of antihypertensive therapy with add-on angiotensin II type 1 receptor blocker after successful coronary stent implantation. Hypertens Res 2009; 32: 625-630.

23 Yamada S, Ano N, Toda K, Kitaoka A, Shiono K, Inoue G, Atsuda K, Irie J. Telmisartan but not candesartan affects adiponectin expression in vivo and in vitro. Hypertens Res 2008; 31: 601-606.

24 Nunez A, Gomez J, Zalba LR, Monton M, Jimenez A, Velasco S, Lopez-Blaya A, Uriarte AC, Casado S, LopezFarre A. Losartan inhibits in vitro platelet activation: comparison with candesartan and valsartan. J Renin Angiotensin Aldosterone Syst 2000; 1: 175-179.

25 Nakayama S, Watada H, Mita T, Ikeda F, Shimizu T, Uchino H, Fujitani Y, Hirose T, Kawamori R. Comparison of effects of olmesartan and telmisartan on blood pressure and metabolic parameters in Japanese earlystage type-2 diabetics with hypertension. Hypertens Res 2008; 31: 7-13.

26 Sasaki T, Noda Y, Yasuoka Y, Irino H, Abe H, Adachi H, Hattori S, Kitada H, Morisawa D, Miyatake K. Comparison of the effects of telmisartan and olmesartan on home blood pressure, glucose, and lipid profiles in patients with hypertension, chronic heart failure, and metabolic syndrome. Hypertens Res 2008; 31 : 921-929. 